\title{
PALEOKARST SHAFTS IN THE WESTERN DESERT OF EGYPT: A UNIQUE LANDSCAPE
}

\author{
PALEOKRAŠKA BREZNA V ZAHODNI PUŠČAVI, EGIPT: \\ EDINSTVENA NARAVA
}

\author{
Ashraf MOSTAFA $^{1}$
}

\begin{abstract}
UDC 551.435.8(620)

Ashraf Mostafa: Paleokarst shafts in the western desert of Egypt: A unique landscape

The Eocene limestone plateau of the Western Desert of Egypt has various karst features, including shafts created during ancient wet periods. These Paleokarst shafts have been investigated on the plateau to the west of the Nile valley, specifically northwest of Assiut. Most of these shafts are infilled by conglomerate (cemented flint, red soil and limestone chips) and appear as pockets in limestone hills. The morphology of the shafts and the characteristics of their infillings suggest that they developed in vadose zone at the base of epikarst limits. This stage probably took place from the end of Early Eocene to the Middle Miocene. A later, different stage of water erosion occurred, most probably during Pliocene/Pleistocene period. This stage led to remove the epikarst zone, and reshaped the area to create a hilly landscape penetrated by infilled shafts. Keywords: Egypt, the Western Desert, karst, shafts, epikarst.
\end{abstract}

Izvleček

UDK 551.435.8(620)

Ashraf Mostafa: Paleokraška brezna v Zahodni puščavi, Egipt: Edinstvena narava

$\mathrm{Na}$ planoti iz eocenskega apnenca $\mathrm{v}$ egipčanski Zahodni puščavi se nahajajo različne kraške oblike, vključno z brezni, ki so nastala v predhodnih deževnejših obdobjih. Ta paleokraška brezna so bila pregledana na planoti zahodno od doline Nila, natančneje severozahodno od Assiuta. Večina teh brezen je zapolnjenih s konglomeratom (strjeni kremen, rdeča prst in apnenčevi odkruški) in se pojavljaji kot žepi v apnenčastih hribih. Morfologija brezen in značilnosti njihovih zapolnitev kažejo, da se se razvila v vadoznih conah, na obrobju epikrasa. Ta faza je verjetno potekala od konca zgodnjega eocena do srednjega miocena. Kasneje, najverjetneje v pliocenskem/ pleistocenskem obdobju, je prišlo do drugačna faze vodne erozije. Ta faza je privedlo do odstranite epikrasa in preoblikovala območje $\mathrm{v}$ gričevnato pokrajino $\mathrm{z}$ zapolnjenimi brezni.

Ključne besede: Egipt, Zahodna puščava, kras, brezna, epikras.

\section{INTRODUCTION}

The Western Desert of Egypt is formed of several plateaus; the largest one is the Eocene limestone plateau which occupies $135 \sim \mathrm{km}^{2}$, i.e., about $20 \%$ of the Western Desert. Most of this plateau extends between the Nile Valley in the east and the depressions of the Western Desert, such as Kharga, Dakhla, Farafra and Bahariya, in the west. The Eocene limestone plateau is currently affected by a hyperarid climate. Therefore, wind action and thermal weathering are the most dynamic geomorphological processes that affect its present surface.

However, this plateau has experienced pluvial periods during the previous geological ages, especially during the Oligocene, Miocene, Pliocene, Pleistocene, and Early Holocene (Ball 1939; Butzer 1959; Said 1981 1983b; Sultan et al. 1997; Ruddiman et al. 1989; Embabi 1999; Brookes 2001; Pickford et al. 2006; Bubenzer \& Riemer

\footnotetext{
${ }^{1}$ Department of Geography, Faculty of Arts, Assiut University, Egypt, e-mail: Ashraffetooh74@yahoo.com Received/Prejeto: 29.09.2010
} 
2007). Several paleokarst features originate from these periods, such as caves, cone karst, karst depressions, shafts, Karren and red soil (EL-Aref et al. 1987; Kuper 1996; Baajens 1997; Waltham 2001; Embabi 2004; Brook et al. 2002; Kindermann et al. 2006; Pickford et al. 2006; Mostafa 2007). Some of these features have been eroded or changed by wind action and thermal weathering, and some others are still preserved in the host rock. Several paleodrainage systems were formed during the previous wet periods (Ball 1939; Salem 1976; Abdel-Rahman \& El-Baz 1979; Said 1981; Said 1983b; Issawi \& McCauley 1993). All the streams of these systems disappeared from the current landscape of the Western Desert; what remains of them are a number of inverted valleys born of topographic inversion in the areas where gravel protected them from erosion (Said 1981; 1983b)

Until recently, our knowledge about the limestone plateau was limited to some field observations made by scientific expeditions which focused on the study of the Nile Valley and its margins, or others that crossed the region traveling between the Nile Valley and the Oases (Ball \& Beadnell 1903; Hume 1925; Sandford 1934; Kuper 1996; Baajens 1997).

Recently, some desert roads have been constructed on the surface of the plateau, the most important of which is the Cairo-Assiut Desert Road and its secondary roads which link it to cities of the Nile Valley. The construction of these roads opened new areas to explo- ration, and led to cutting in many limestone hills that stood in the way of the roads, and has made it possible to see unexplored paleokarst features. The quarries of Assiut cement factory also helped investigate some of these karstic characteristics.

The present study focuses on the shafts and their infillings on the Eocene limestone plateau, just west of Assiut between latitudes $27^{\circ} 07^{\prime} \& 27^{\circ} 11^{\prime} \mathrm{N}$. and longitudes $30^{\circ} 46^{\prime} \& 31^{\circ} 00^{\prime} \mathrm{E}$. Assiut is located in the central part of the Nile Valley of Egypt, about $375 \mathrm{~km}$ south of Cairo (Fig. 1). The investigation area is characterized by several karst features like shafts, grikes, collapsed caves, red soil, and red breccia. The most attractive feature is the conglomerate infilled shafts which penetrate the limestone hills (Fig. 2). The present study aims at detecting and analyzing the geomorphological aspects of these shafts and their infillings. Finally, it seeks to give an account on the geomorphological evolution of this part of the Western Desert. 21 different shafts have been investigated in the field. Size, shape, sorting, roundness, and orientation of 170 pieces of shaft infillings have been investigated. 5 samples of red soil have been analyzed by $\mathrm{X}$-ray diffraction.

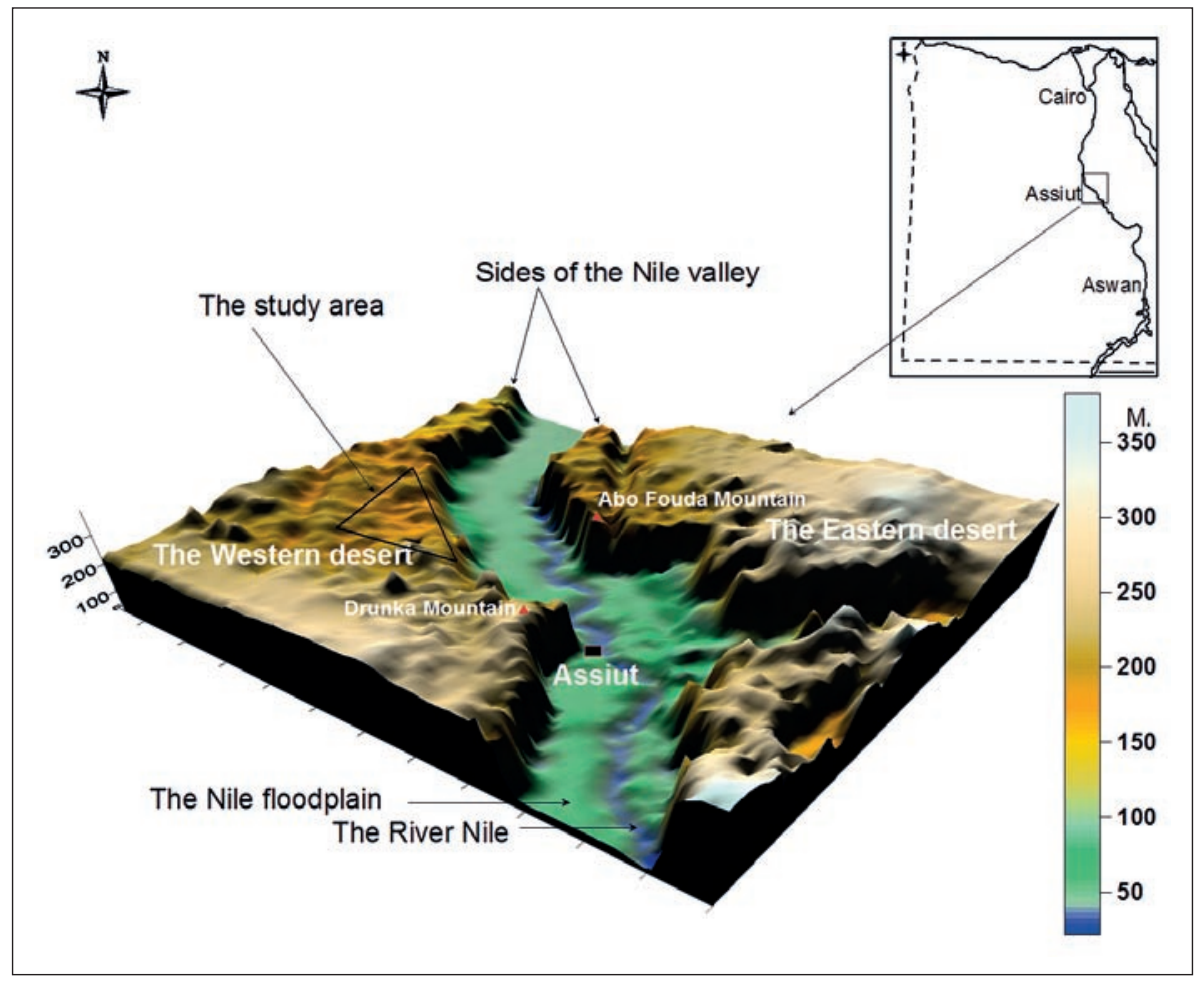

Fig. 1. Location map of the study area, and a 3D model illustrating the topography of the area. 


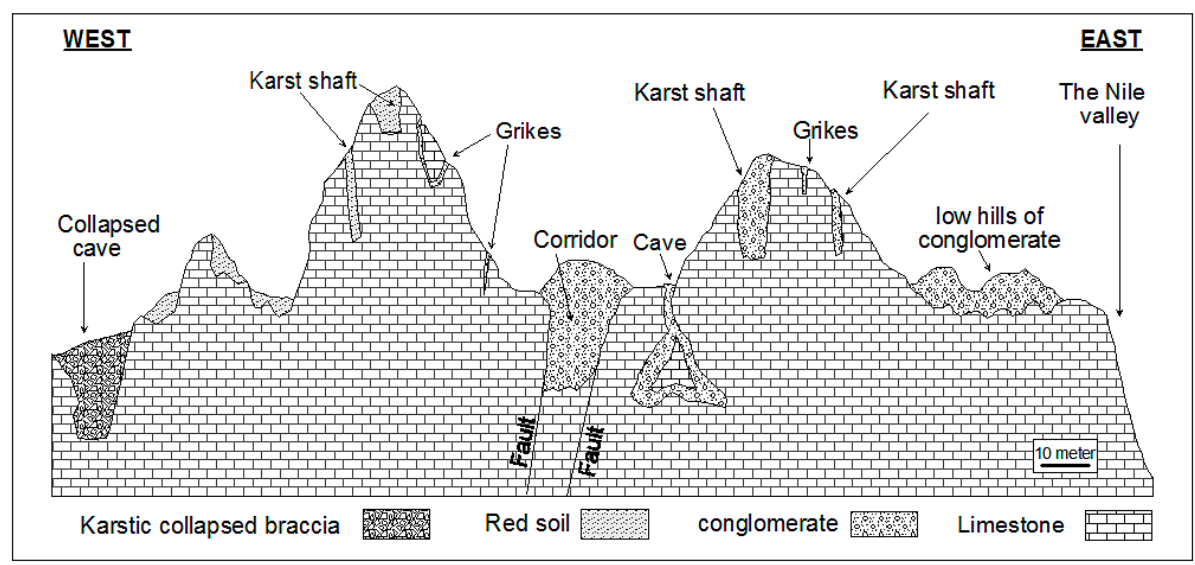

Fig. 2. A sketch illustrating the different forms of palaeokarst on the limestone plateau.

\section{GEOLOGICAL AND GEOMORPHOLOGICAL SETTING}

The study area is predominantly composed of Lower Eocene limestone. The carbonate succession is subdivided into Drunka and Minia formations. (Fig. 3) (Klitzsch et al. 1987). Drunka formation is composed of medium to thick-bedded, creamy to snow white, highly fossiliferous chalky limestone, locally bioturbated, carbonate mudstone and wackestone that contains large concretions and local flint bands (Youssef et al. 1982; Klitzsch et al. 1987; McBride et al. 1999; Abu El Ghar \& Hussein 2005). Several dissolution deposits have developed in Drunka formation, such as red soil, karst breccia, and calcite precipitates. Minia formation is composed of well-bedded white to grey alveolined lagoonal to marine limestone (Klitzsch et al. 1987; Abu El Ghar \& Hussein
2005). Most of the hills spreading on the surface of the study area belong to this formation.

The Eocene limestone is covered by surface sediments of more recent age, such as; gravel, aeolian sand, red soil, and red breccia. The latter appeared in flat plains and inside some karst depressions. The most important of these sediments is gravel. There are two types of gravel in the study area (Said 1981; Klitzsch et al. 1987): the first one constitutes separated gravel mounds. Said (1983b) states that these mounds, which are ranging in some areas from 2 to $20 \mathrm{~km}^{2}$, are considered relics of a drainage system which flowed on the Eocene plateau during the pluvial periods of the Oligocene age. These gravel mounds have been interpreted as Oligocene's in-

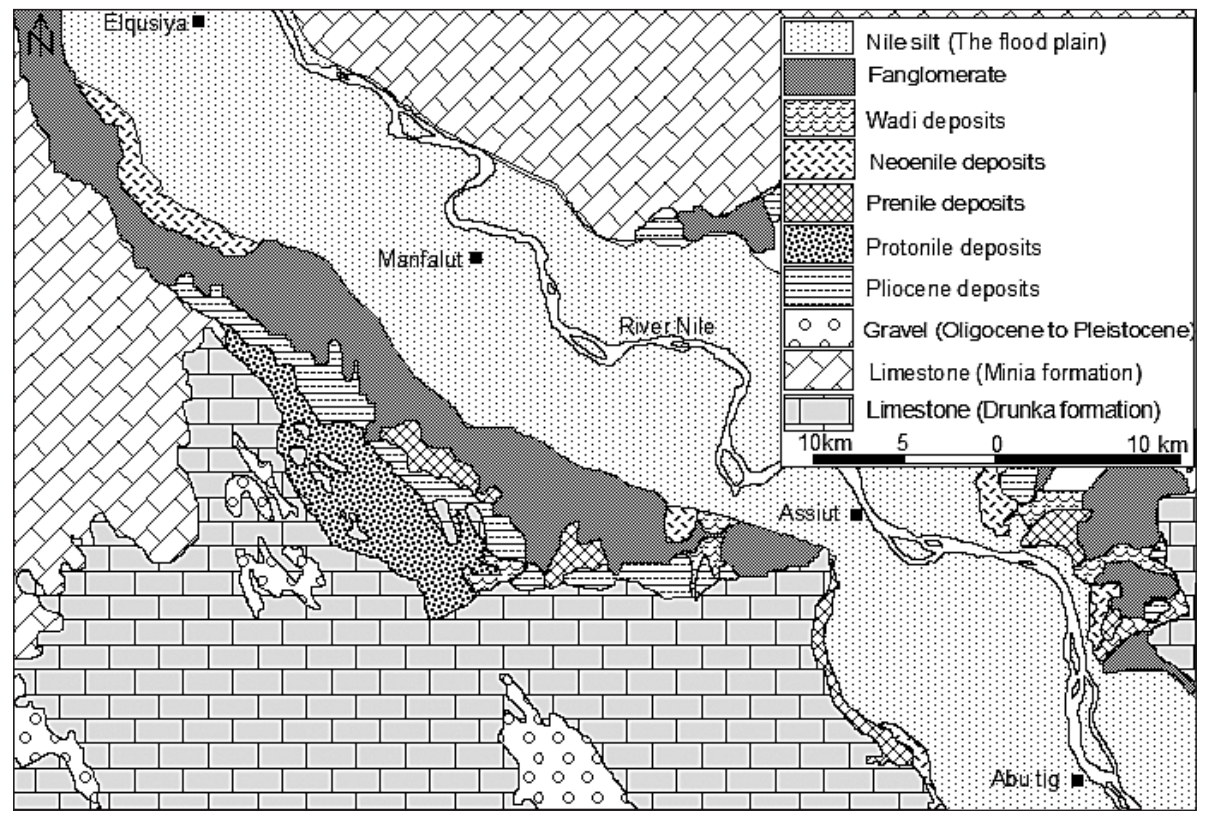

Fig. 3. Geological map of the study area (Klitzsch et al. 1987). 
verted valleys. Klitzsch et al. (1987) determined their age between Oligocene to Pleistocene. The second kind of gravel deposits is found in a small area at the edge of the Nile valley. This gravel was deposited by the Protonile River of the third Nile river system that flowed in the Nile Valley by the end of Early Pleistocene (Said 1983a). This River system came after two previous river systems; the Eonile River, which incised the Nile valley during Late Miocene between 5.96 and $5.32 \mathrm{Ma}$. and the Paleonile River which was formed during Late Pliocene, about 3.3 Ma. (Said 1983a). This gravel created turtlebacks-like hills landscapes or helped form the Protonile's inverted valleys, according to Said (1981) and Said (1983a).

From a geomorphological point of view, the area is a part of the Western Plateau which extends along the Nile Valley. The height of the plateau ranges between 100 $\mathrm{m}$ and $185 \mathrm{~m}$ above sea level, and between 50 and $135 \mathrm{~m}$ above the present Nile River flood plain, which is itself $50 \mathrm{~m}$ asl in the area (fig. 1). The plateau has small, dry drainage streams which drain into the Nile Valley. These streams have been formed during previous pluvial periods. A large number of limestone hills, between 5 and 30 $\mathrm{m}$ in height, spread over the investigated area. Most of these hills are linear or semi-circular in shape. A few of these hills, particularly those of low height, are covered with gravel. In most cases the gravel is only to be found within the shafts (karst pockets) that dot these hills. Another type of hills, mainly made of conglomerate, is concentrated in the eastern part that looks over the Nile Valley. Most of these hills display a turtleback pattern, rising between $3 \mathrm{~m}$ and $8 \mathrm{~m}$.

To the west and away from the Nile Valley prevails a peculiar phenomenon, i.e., giant flutes (linear depressions), which sometimes extend up to more than $30 \mathrm{~km}$ and range between $100 \mathrm{~m}$ and $10 \mathrm{~km}$ in width (Brooks 2001). Some of them are called "valleys" in the old topographic maps, their orientation is northwest-southeast. Brooks (2001) attributed their development to a catastrophic flood during the Miocene times.

It is important to mention that the upper surface of the southern part of the study area is characterized by an epikarstic zone several meters thick. This zone, as the upper most weathered zone of the karstic rock (Klimchouk 2004; Bakalowicz 2005; Williams 2008), does not appear clearly on the upper part of the hills, but it can be observed on the surrounding southern high areas of the plateau.

\section{SHAFTS MORPHOLOGY}

The shafts are the most common type of karst features in the study area. They are vertical to sub-vertical pipes, their shape rounded to elongated, and always filled with conglomerate. Their size ranges between 1.5 to $5.0 \mathrm{~m}$ in diameter and more than $8 \mathrm{~m}$ in depth. Generally, the depth of the shafts exceeds their width (Fig. 4a).

These shafts are restricted to the surface of the limestone hills. The reddish brown conglomerate infilling makes it easy to distinguish the boundaries of the shafts (Fig. 4b). Many of these irregularly distributed shafts have been revealed during the construction of new roads in the area and in the exposed quarries. The shafts can be isolated or be grouped in more complex spatial distributions, when they link with other shafts or occur in groups, as in the so-called "shaft complexes" described by Brucker et al. (1972). In many cases, the rounded shafts turn to elongated shafts (small canyons or gorges) which range between 1-6 $\mathrm{m}$ in length, and $0.6-1.3 \mathrm{~m}$ in width. The directions of the longitudinal axis of these shafts are variable and some of them do not seem related to linear fissures. Such canyons can be attributed to the retreat of the shaft's side along the flutes as feeder, undersaturated water flows down (Brucker et al. 1972; Hess 2005).
The shaft infillings, which will be analyzed in the next section, consist of cemented gravel and red soil. Sometimes, it contains limestone chips and blocks. The upper surface of such infillings stands up as a positive relief feature among the limestone rocks.

On the walls of some vertical shafts, which have been artificially emptied from their infillings, there are some flutes or longitudinal rills which are concentrated on one side only. They vary in size from 5 to $30 \mathrm{~cm}$ in width, and more than $180 \mathrm{~cm}$ in length (Fig. 4c), often extending along the filled lower parts of the walls. The size of these flutes, especially their width, is large compared with the shaft itself. They are produced by the corrosional and erosional action of the falling water or flow film along the shaft walls (Swetting 1972; Baroñ 2003). The discharge and velocity of the water must remain low enough to allow the flow to remain attached to the wall as a film flow, rather than a channel flow (Lundberg 2005). The upper parts of the shaft wall are penetrated by vadose tubes or small drainage channels, whose diameter is smaller than $10 \mathrm{~cm}$. These channels are infilled by a mixture of sand and small gravels (Fig. 4d). 

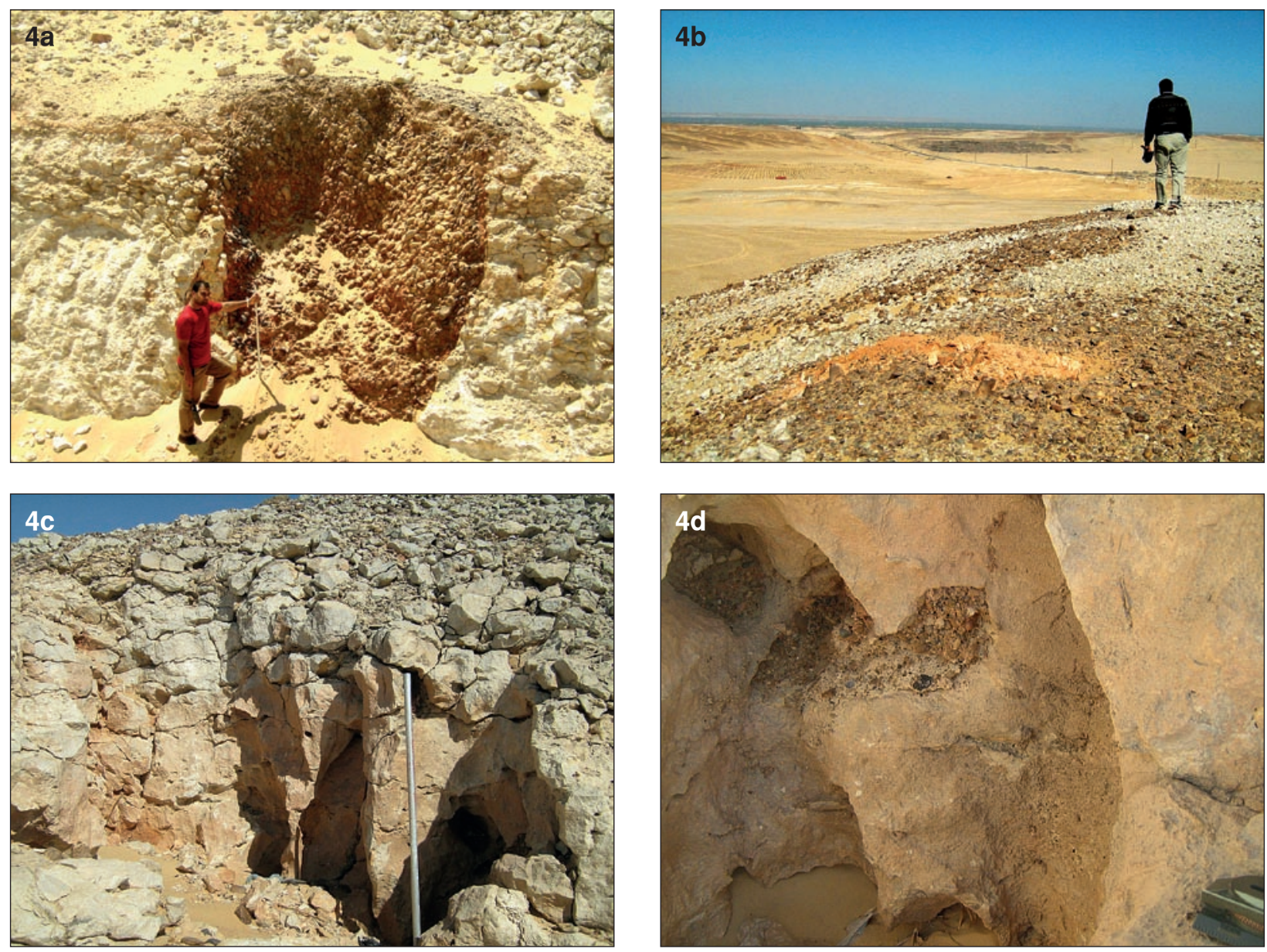

Fig. 4. Characteristics of the shafts. (A) Side view of a vertical shaft filled with conglomerate. (B) Some shafts atop a limestone hill, it can be determined by the dark colour of conglomerate or red soil infillings. (C) Some flutes formed on the side of the shaft. (D) Small vadose tubes have been formed on the shaft sides.

South of the study area, the shafts have developed at the base of epikarst zone with a thickness ranging be- tween 2 and $6 \mathrm{~m}$. Most of theses shafts have been created along main structural lines (Fig. 5).

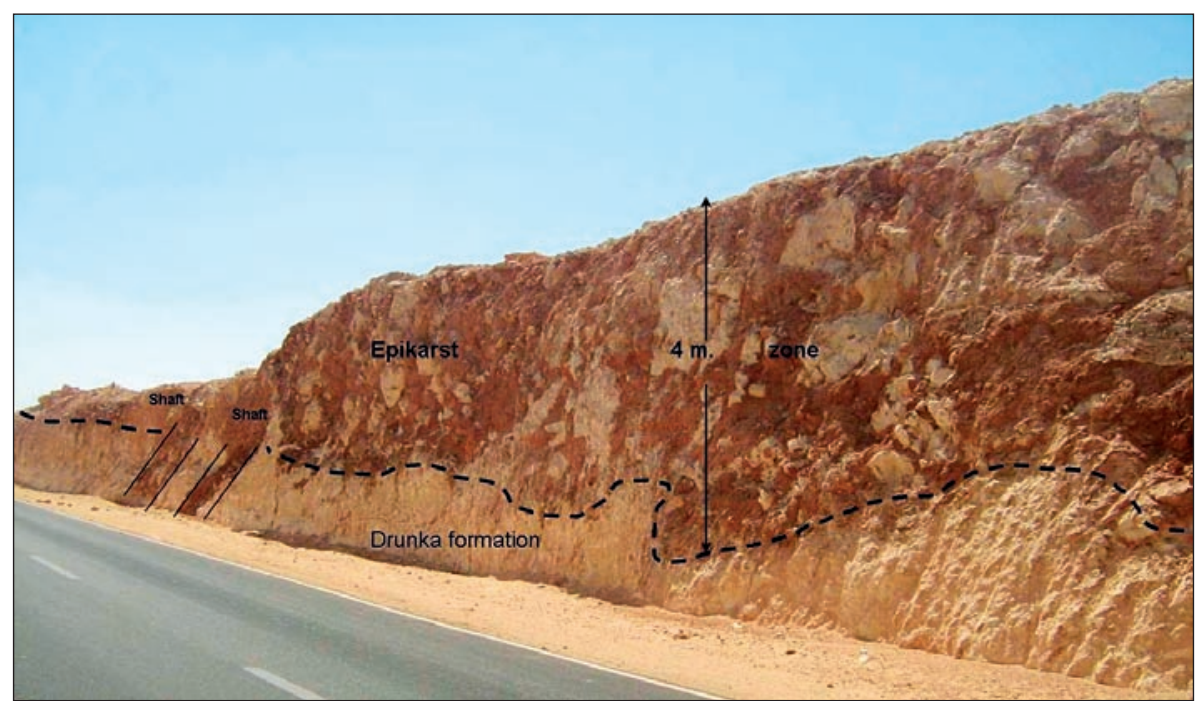

Fig. 5. Relicts of the epikarst zone of the Eocene limestone plateau south of the study area, some shafts have been formed at the base of this zone. 


\section{SHAFT INFILLINGS}

Two types of infillings can be found inside the shafts; the first is conglomerate, and the second is red soil and red breccias.

\section{CONGLOMERATE}

Conglomerate is a cemented mixture of gravel, coarse sand and brownish red, loamy materials. The matrix sometimes contains small angular chips and blocks of limestone (Fig. 6). It is important to mention that the conglomerate either inside the shafts or in turtlebacks hills have the same characteristics. Five samples of conglomerate have been examined. The long (L), intermediate (I), short (S) axes, and shape (morphology) of 170 pieces of gravel have been measured. Gravel account for between $82 \%$ and $93 \%$ of the conglomerate volume. Gravel size is between 1.2 and $15 \mathrm{~cm}$, and the mean size is $5.5 \mathrm{~cm}$ long. It is poorly sorted to very poorly sorted, subangular to well rounded. About $53 \%$ of the samples are rounded, and $97 \%$ of the gravel ranges between subrounded to well rounded. Using Zing's shape index, about $43.5 \%$ of the samples are prolate, $25.9 \%$ are equant, $21.8 \%$ are oblate, and about $8.8 \%$ have a bladed shape (Fig. 7). The main value of Wadell's sphericity ( $3 \sqrt{ }$ IS/L2) is 0.67 (i.e. medium sphericity), $43 \%$ of the samples are between 0.6 and 0.69 , and $37.6 \%$ range between 0.7 to 0.79 . No preferred orientation can be recognized in most sections of the gravel inside the shafts, and it lacks bedding. In a few cases, the gravel elongation inside the shafts takes an updown orientation. The morphological characteristics of the gravels seem to indicate a complex origin and forma- tion. However, two types of gravel can be distinguished in the conglomerate (Oligomict conglomerate).

The first type is flinty gravel or chert nodules which are the most common (92\%) and whose size is the biggest (Fig. 8a) (the mean size is $5.7 \mathrm{~cm}$ ). The actual shape (morphology) of chert gravel is determined by its initial morphology, which is inherited from the source rock (Lindholm 1987).These nodules are left behind on the surface as a result of limestone dissolution (Embabi 2004). One of the most important features that distinguish this type of gravel is the presence of deep chemical weathering holes which reach $4.0 \mathrm{~cm}$ in diameter and 3.5 $\mathrm{cm}$ in depth (Fig. 8b). In addition, it appears from the internal structure of the split gravels that the weathering goes as deep as several millimeters into the gravel. In some cases, the surface of the gravel and the sides of the shafts are covered with a white calcareous crust, especially in the upper parts of the shafts.

The second type of gravel is quartz, which is smaller and less common than flint $(2 \mathrm{~cm}$ long and $8 \%$ of the sample number) (Fig. 8c). The presence of quartz points to a distant source other than the surrounding limestone plateau.

The conglomerate sometimes contains elongated and sub-angular limestone blocks of host rock. The char-

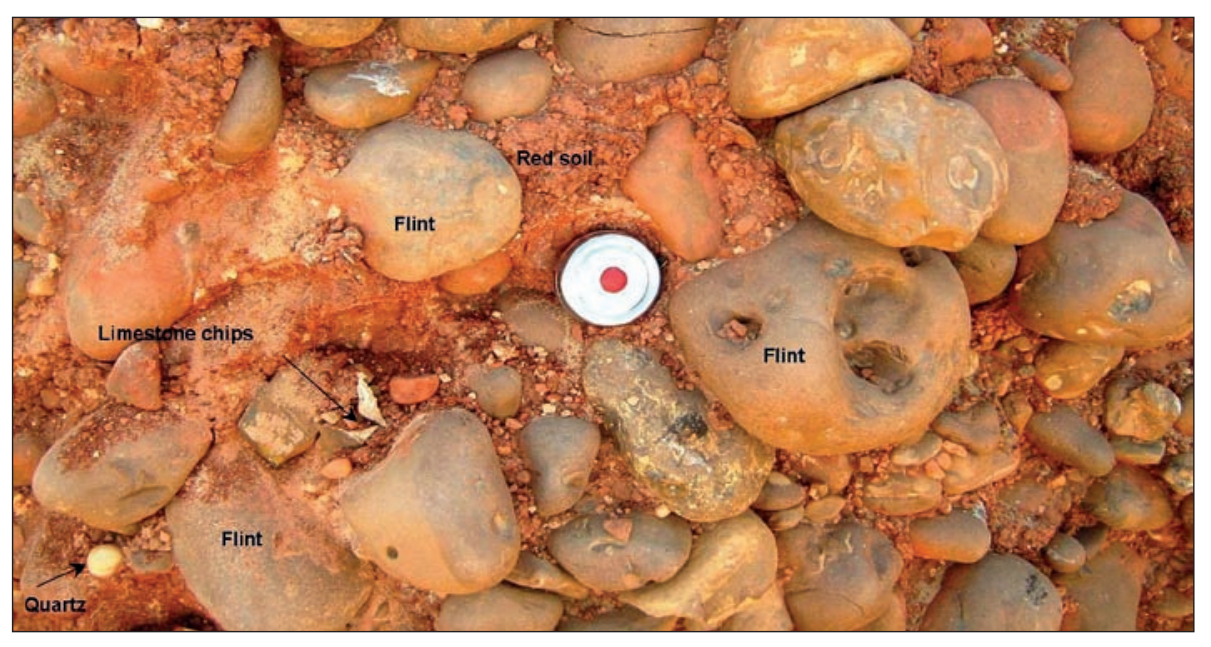

Fig. 6. The different components of the conglomerate inside the shafts 


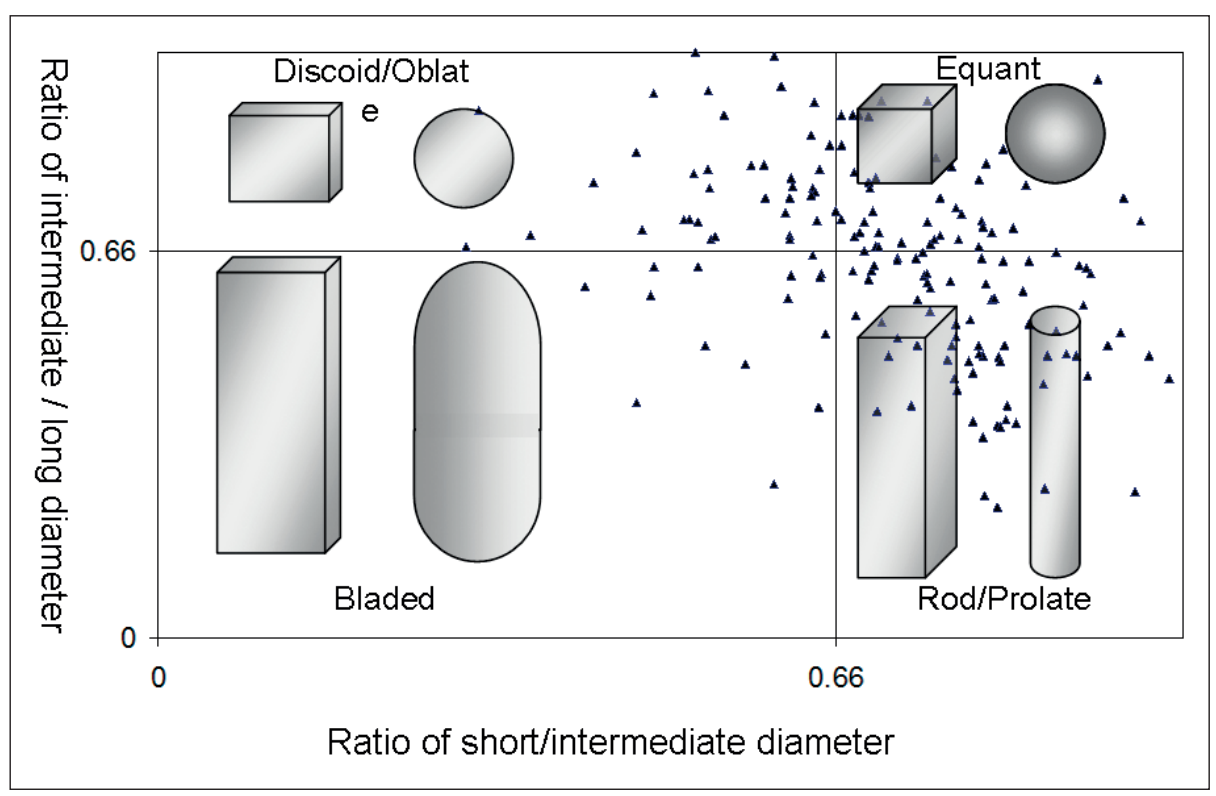

Fig. 7. The shape of the gravel of the conglomerate according to Zing's shape index.
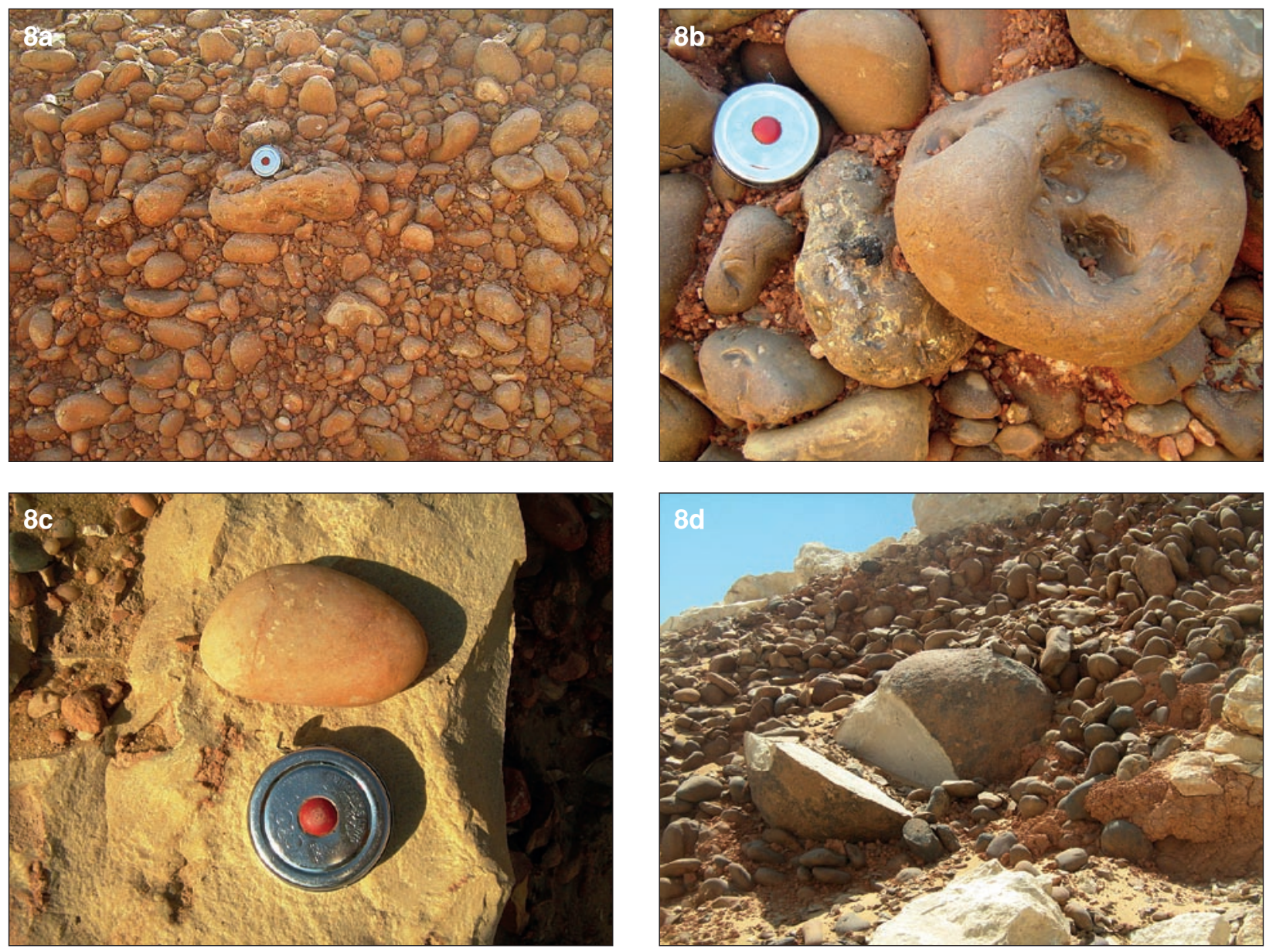

Fig. 8. Characteristics of the conglomerate and its composition, (A) flinty gravels forming most of the conglomerate that is cemented by red soil without internal layers. (B) Flinty gravels extremely affected by deep pits of chemical weathering (C) Quartz pebbles transported from outer limestone plateau. (D) Melon concretions produced also by limestone dissolution and mixed with the gravels (The diameter of the tab is $5 \mathrm{~cm}$ ). 
acteristics of the blocks indicate that they were not transported over long distances. Several dissolution pipes, whose mean diameter is $5 \mathrm{~cm}$, have been formed in these blocks, and nearly all the sides of the blocks have been affected by these pipes.

At some locations, either inside the shafts or in the conglomerate of the turtlebacks hills, there are silica (melon) concretions, which are left behind on the surface after limestone dissolution (Embabi 2004). These concretions, which are embedded in the conglomerate, are well-rounded with high sphericity, and their diameter ranges between $40 \mathrm{~cm}$ and $110 \mathrm{~cm}$ (Fig. 8d). Melon accumulations or fields are a common feature on the limestone plateau of the Western Desert, either as residual materials on the surface or as buried materials in the bedrock (Mc Bride et al. 1999; Embabi 2004), but melons have never been found embedded in conglomerate, as they are in the study area. Inspecting the internal structure of the split concretions and examining three thin sections of the melon show that these concretions are similar to those which belong to Drunka and Minia formations. This indicates that such melons have developed inside the area.

\section{RED SOIL AND RED BRECCIA}

Red soil is composed of a reddish brown, loamy, clayrich to sandy materials which originate in limestone dissolution. These residual materials are sometimes mixed with small and angular limestone fragments (Fig. 9a, 9b). Sandford (1934) called this material "sandy red breccia" On the limestone plateau, between the Nile valley and Kharga depression, red soil and red breccias have been documented by Caton-Thompson \& Gardener (1932), Sandford (1934) and Embabi (2004). According to Embabi (2004) these sediments can be found in three types of locations: on the floors of shallow depressions, transported there as washed materials: below silica gravel sheets that provide a protection: or as infilling pockets.

The red soil in the study area can be found in four different topographic sites; inside the shafts, in epikarst zone, mixed with the conglomerate of the turtleback hills, and on the floor of some vast depression. The last type, according to Caton-Thompson \& Gardener (1932) and Embabi (2004) is the result of residual karstic materials washed into the depressions by running water. It may be transported by a sheet flood on a short distance.

$\mathrm{X}$-ray diffraction analysis of different types of such red soil shows occurrence of quartz, calcite, gypsum, illite, smectitc, and halite. Red soil of the shafts, epikarst, and turtle-back hills are quite similar.

The red breccia in the investigated area is similar to Issawia formation which appeared at many places in the Nile Valley, such as Issawia area at the eastern side of the Nile valley (90 km south of the study area). Said (1981) attributes Issawia formation, which consists of red breccia, to tectonic events which occurred during the early Pleistocene (Paleonile/Protonile interval), whereas Ahmed (1992) attributes this formation to karstification.
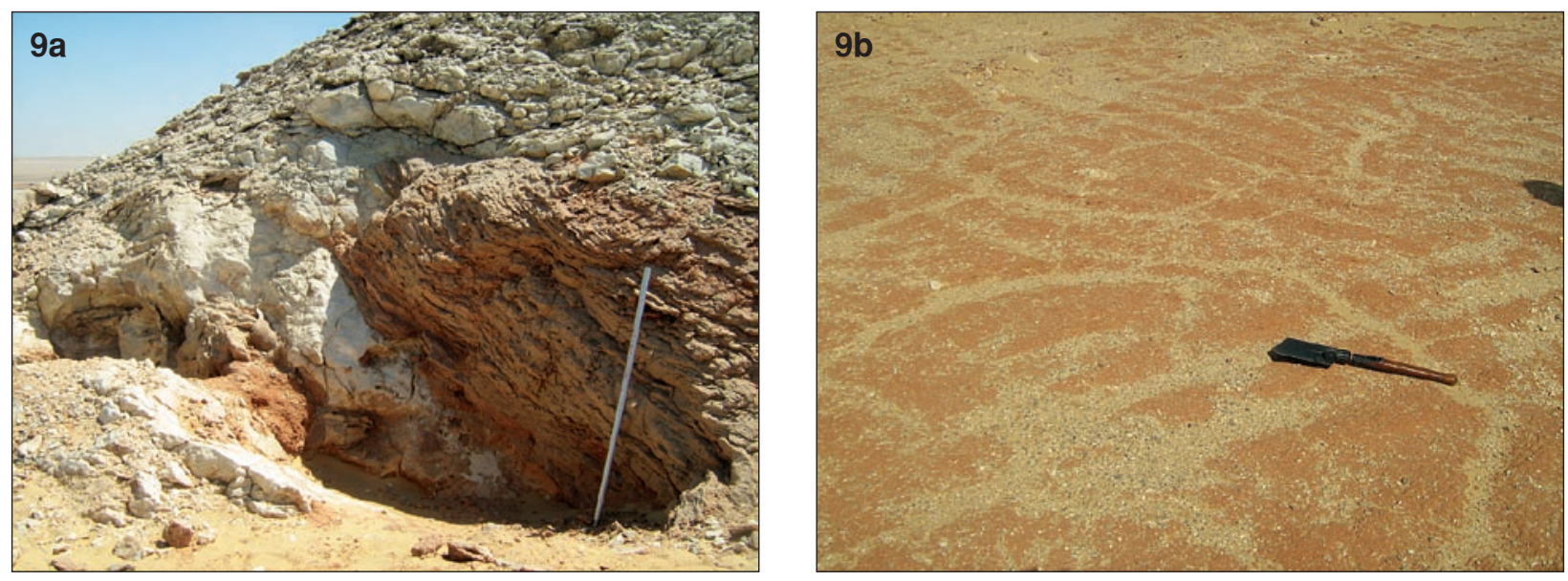

Fig. 9. Red soil on the limestone plateau (A) Red soil deposited inside shafts and grikes of limestone hills, (B) Red breccia plains have been originated in some vast depressions. 


\section{DISCUSION}

The characteristics of the infillings and morphology of the shafts allow for the determination of the shaft origin, and the geomorphological evolution of the study area .

The gravel, which is the most frequent component of the conglomerate, consists chiefly of flint or chert. This flint, most probably, derives from Drunka formation which is flint-rich. It means that most of the gravel originated from the surrounding Eocene limestone plateau, and this plateau has been affected by extensive dissolution that produced large amounts of residuals.

The presence of deep weathering holes and dark rings of weathering on the flint and melon concretions point to the prevalence of pluvial conditions for a long period or periods. It is likely that flinty gravels were developed in a fairly deep soil or regolith in the presence of a vegetation cover. In such environmental conditions, deep weathering of solid flint can occur (Prelovšek 2005). This feature also requires that such gravel has remained stable for a long time. Presence of angular limestone blocks and chips of Drunka formation, mixed with the conglomerate confirm that these sediments were not transported over a long distance.

The hardness of the flint and the cementation of the conglomerate made this mixture more resistant than the host rock. Therefore, the mouths of the shafts look relatively higher than the surrounding limestone surface, which was eroded at a faster rate due to its weakness. On a larger scale, this phenomenon led to topographic inversion; the longitudinal conglomerate hills $(150 \mathrm{~m}$ in length, $8 \mathrm{~m}$ in width) which have a turtleback shape may be attributed to the deposition of gravel inside linear depressions or corridors. After eroding the bedrock, the gravel mounds became salient topographical features in the area. Several of these hills were reshaped by subsequent running water erosion. It is important to mention that some of these infilled depressions are still preserved, some of them are exposed by quarrying.

The source and age of the gravel in the study area are debated. Said (1981), Said (1983b) and Klitzsch et al. (1987) attributed the gravel in the investigated area to the old Nile fluvial gravel of the Protonile River (Idfu formation). Said points out that the fluvial sediments of the Protonile River are

"... in the form of complex gravel, coarse sand, and loamy materials....since most of the gravels of the Protonile are made up of flint and quartz, it must be assumed that these must have been derived from a deeply leached terrain which was subjected to intensive chemical weathering ... The gravels of the Idfu Protonile have a red soil which is probably the most distinctive characteristic of the sediment." (Said 1981, p.50)

Some evidence confirmed the Nile origin theory of the gravel; the Protonile River was the most westward river to flow since the inception of the River Nile at the end of the Miocene Age (Said 1981). It has been established that the Protonile River flowed on the bedrock in some of its sections in middle Egypt, and therefore, its sediments directly rested in unconformity on the Eocene limestone (Said 1981). The geological map shows that among Nile sediments, only the Protonile gravel of Idfu formation extends on the surface of the western limestone plateau as a side wedge towards the west (Fig. 3). Said (1981) estimated the level of the Protonile River to be between 80-100 $\mathrm{m}$ above the current flood plain.

According to this theory, it can be inferred that paleokarst pockets on the plateau are older than the Idfu formation which was deposited by the Protonile River. Said (1983a) has suggested that the Idfu formation dates from the end of the early Pleistocene Age. Since the climate of the early Pleistocene in Egypt was hyperarid for one million years (Said 1983a; Embabi 2004; Sultan et al. 1997), paleokarst pockets are most probably older than the early Pleistocene. At the same time, they cannot be older than the Early Eocene, because karst can not be older than the rocks that contain it (White 1988). Consequently, the estimated age of paleokarst pockets, based on the Protonile gravel age, is middle Eocene to Pliocene. The reddish lomy materials (Terra Rosa), according to Said 1981, have been developed on the Protonile gravel as red soil during later wet periods.

Acceptance of the Protonile theory as a source for the gravel in the investigated area is open to discussion. The presence of the gravel at $185 \mathrm{~m}$ above sea level, and $135 \mathrm{~m}$ above the present flood plain raises an important question: How did the Protonile reach this elevation? The maximum elevation for the Protonile sediments, as estimated by Said (1981), is $100 \mathrm{~m}$. No new tectonic uplift has been recorded in the study area (Youssef et al. 1982).

On the other hand, the existence of these immense amounts of flinty gravel that resulted from limestone dissolution, and its distinctive chemical weathering features, point to past intensive pluvial periods, thick soil, and dense vegetation cover. These environmental conditions are different from the hyperarid climate of the first million years of the Pleistocene time in Egypt. At the same time, no features of arid conditions (such as wind erosion or thermal weathering) have been evidenced on the gravel surface. Another proof, which confirms the 
heterogeneity of the gravel in the study area and the Protonile River, can be derived from satellite imagery; recent Landsat images of the area show that the gravel accumulation in the study area has been cut by the Messinian Eonile canyon of the late Miocene. It indicates that the gravel has been deposited before the late Miocene.

The present study suggests that the age of the gravel is older than the late Miocene. The characteristics of the chemical weathering holes in the flinty gravel require a long wet climate, soil, and vegetation cover to form. It is probable that these gravels have been affected by several cycles of chemical weathering. The surrounding Eocene limestone plateaus have been affected by several pluvials since the end of Lower Eocene, It is probable that the gravel has been derived from its bedrock since that time. It is important to mention that upward tectonic movement took place at the end of the Lower Eocene and this necessarily resulted in greater denudation (El-Nakkady 1958; Said 1962). The Eocene karstification cycle, according to Embabi (2004), is one of the oldest karstification cycles in Egypt.

More gravel have been created and/or reshaped by chemical weathering during the subsequent pluvials of the Oligocene-Miocene period. Embabi (2004) concluded that the Oligocene-Miocene karstification cycle is the most significant one in the karstification evolution of Egypt; it was the longest cycle as it lasted for about 30 million years.

The absence of bedding in the conglomerate and the presence of angular limestone blocks and chips indicate that these gravels were not affected by running water neither over a long distance nor for a long time. So that it is probable that the effect of the Oligocene-Miocene period in the study area is restricted to chemical weathering rather than water erosion.

The presence of Eocene - Oligocene/Miocene gravels only in the pockets rather than on the rest of the surface of the limestone hills means that the gravel-covered karstic surface has been affected by a more recent erosion cycle or cycles. Such cycles were responsible for removing the surface gravel from the surrounding areas, especially the high lands, and eroding the limestone to form the current hilly landscape. Most probably this landscape has been formed during the wet phases of the Pliocene/Pleistocene. It is likely that the gravel, which accumulated in the low areas as large, thick deposits, has been reshaped into turtlebacks hills during Pliocene/ Pleistocene times.

The development of some shafts in the vadose zone at the base of epikarst limits is an important indicator for the origin of the studied shafts. This is consistent with Klimchouk's model $(1996,2004)$ and Baron's model (2002) of shaft development at the base of epikarst. Although most of the epikarst zone has been removed above the hills by later erosional stages during Pliocene/Pleistocene times, there are some indicators that confirm this epikarstic origin of the shafts; presence of the flutes on the sides of the shafts indicate that these shafts have been formed in vadose zone. Such flutes (troughs) are similar to those found in Baroñ's study (2002). The surface of the hills still retains some Karren features (such as grikes and clints) which are one of the characteristics of the epikarst zone (Klimchouk 1996; Klimchouk 2004; Bakalowicz 2005; Rodrigues 2011). According to the above aspects, the limestone blocks which are embedded in the conglomerate can be explained by ceiling breakdown or as remnants of the epikarst zone. The dissolution pipes which are formed in such blocks may be interpreted as subsoil Karren (Bakalowicz, 2005; Williams 2008). This indicates that the gravel and red soil were formed in situ.

The presence of large melon concretions mixed with angular limestone blocks without any bedding or Palaeocurrent structure in the conglomerate can be explained by the mode of development of the shafts in the epikarst zone's hypothesis. Also, the richness of the epikarst zone in soil and natural plants (Klimchouk 2004; Williams 2008) can explain the remarkable weathering holes on the hard flint and silica concretions. Epikarst zone conditions provide an environment likely to explain the characteristics of the shafts and their infill in the investigated area.

\section{CONCLUSION}

The morphology of the shafts, and the characteristics of their infillings point to an origin to be found in the vadose zone at the base of epikarst limits. Most probably, these shafts and their infill have been formed since the end of Lower Eocene to Middle Miocene. The epikarst zone has been removed mainly by subsequent water erosion, possibly during the Pliocene/Pleistocene period.
Therefore, the conglomerate is restricted to the shafts, whereas the rest of the hill's surface is free of such sediments. According to the present study, some of the inverted wadis sediments, which were evoked in previous studies, can be explained as relicts of the epikarst zone of the Eocene limestone plateau of Egypt. 


\section{REFERENCES}

Abdel-Rahman, M., \& F. El-Baz, 1979: Deposition of a probable ancestral delta of the Nile River.- in: ElBaz, F. \& D. Warner (eds.) Appolo-Soyuz Test Project, Vol. II, Earth Observations and Photography, NASA, pp 511-520, Washington DC.

Abu El Ghar, M. \& A. Hussein, 2005: Post-depositional changes of the Lower-Middle Eocene limestone of the area between Assiut and Minia, west of the Nile Valley, Egypt.- First International Conference on the Geology of the Tethys, November, Cairo University, 37-57, Cairo.

Ahmed, S., 1993: Collapse and solution red breccia of the Issawia Sharq locality, Nile Valley, Upper Egypt.Egyptian Journal of Geology, 37, 187-203.

Baajens, A., 1997: Geographical observations in the Western Desert of Egypt.- Bull. Soc. Géogr.d'Égypte, 70, 203-213.

Bakalowicz, M., 2005: Epikarst.- in Culver, D. \& W. White (eds.) Encyclopedia of caves, Elsevier Inc. pp. 220-223, Burlington.

Ball, J., 1939: Contribution to the geography of Egypt.Survey \& Mines Department, Government Press, PP. 308, Cairo.

Ball, J. \& H. Beadnell., 1903: Bahariya Oasis: Its topography and geology, Egypt.- Survey Department, PP. 84, Cairo.

Baroñ, I., 2003: Speleogenesis along sub-vertical joints: A model of plateau karst shaft development: A case study: the Dolný Vrch Plateau (Slovak Republic).Speleogenesis and Evolution of Karst Aquifers. The Virtual Scientific Journal. [Online] Available from: http:// Speleogenesis. Info

Brook, G., Embabi, N., Ashour, M., Edwards, R., Cheng, H., Cowart, J. \& A. Dabous, 2002: Djara cave in the Western Desert of Egypt: Morphology and evidence of Quaternary climatic change.- Cave and Karst Science, 2, 57-66.

Brooks, I., 2001: Possible Miocene catastrophic flooding in Egypt's Western Desert.- J. African Earth Science, 22, 325-333.

Brucker, R., Hess, J., \& W. White, 1972: Role of vertical shafts in the movement of ground water in carbonate aquifer.- Ground water, 10, 5-13.

Bubenzer, O. \& H, Riemer, 2007: Holocene Climatic Change and Human Settlement between the Central Sahara and the Nile Valley: Archaeological and Geomorphological Results. Geoarchaeology: An International Journal, 22, 607-620.

Butzer, K., 1959: Some recent geological deposits in the Egyptian Nile Valley.- Geogr. Jour., CXXV, PP. 75-79.
Caton-Thompson, G. \& E. Gardener, 1932: The Prehistoric geography of Kharga Oasis.- Geogr. Jour., LXXX, 369-409.

El Aref, M., Abou Khadrah A. \& Z. Lotfi, 1987: Karst topography and karstification processes in the Eocene limestone plateau of El Bahariya Oasis, Western Desert, Egypt.- Z. Geomorph. N. F., 31, 45-64.

El-Nakkady, S., 1958: Stratigraphic and petroleum geology of Egypt.- Monograph series, 1, University of Assiut, PP. 215, Assiut.

Embabi, N., 1999: Playas of the Western Desert, Egypt.Ann. Acad. Sci. Fennicae, Geologica-Geographica, 160, 5-47.

Embabi, N., 2004: The geomorphology of Egypt: Landforms and Evolution, Vol. 1, The Nile Valley and the Western Desert.- The Egyptian Geographical Society, pp. 447, Cairo.

Hess, J., 2005: Pits and shafts.- in: Culver, D. \& W. White (eds.) Encyclopedia of caves, Elsevier Inc. pp. 444447, Burlington.

Hume, W., 1925: Geology of Egypt, Vol. 1, Survey of Egypt.- Government Press, Ministry of Finance, pp. 408, Cairo.

Issawi, B., \& J. McCauley, 1993: The Cenozoic Landscape of Egypt and its River System.- Annals Geol. Survey Egypt, 19, 357-384.

Kindermann, K., Bubenzer O., Nussbaum S., Riemer H., Darius F., Pollath N. \& U. Smettan, 2006: Palaeoenvironment and Holocene land use of Djara, Western Desert of Egypt.- Quaternary Science Reviews, 25, 1619-1637.

Klimchouk, A., Saura, U. \& M. Lazzaroto, 1996: "Hidden" shafts at the epikarstic zone: a case study from the Sette Communi plateau, Venetian Pre-Alps, Italy.- Cave and Karst Science, 23,101-107.

Klimchouk, A., (2004) Towards defining, delimiting and classifying epikarst: Its origin, processes and variants of geomorphic evolution).- Speleogenesis and Evolution of Karst Aquifers. The Virtual Scientific Journal. [Online] Available from: http:// Speleogenesis. Info

Klitzsch E., List F. \& G. Pohlimann, 1987: Geological map of Egypt. 1:500000, NG 36 NW Asyut.- Conoco Coral and the Egyptian General Petroleum Corporation, Cairo.

Kuper, R., 1996: Between the Oases and the Nile-Djara: Rohlfs Cave in the Western Desert, Interregional Contacts in the Later Prehistory of Northeastern Africa.- Archaeological Museum, pp. 81-91, Poznan. 
Landberg, J., 2005: Karren.- in: Culver, D. \& W. White (eds.) Encyclopedia of caves, Elsevier Inc. pp. 315321, Burlington.

Lindholm, R., 1987: A practical approach to Sedimentology.- ALLEN \& UNWIN, pp. 276, London.

McBride E., Abdel-wahab A. \& A. El-Younsy, 1999: Origin of spheroidal chert, Drunka Formation (Lower Eocene), Egypt.- Sedimentology, 46, 733-755.

Mostafa, A., 2007: Karst geomorphology of the Farafra Depression, the Western Desert, Egypt.- Ph. D. thesis (in Arabic). Department of Geography, Faculty of Arts, Ain Shams University, Cairo. pp. 374.

Pickford, M., Wanas, H, \& H. Soliman, 2006: Indications for a humid climate in the Western Desert of Egypt 11-10 Myr ago: evidence from Galagidae (Primates, Mammalia).- General Palaeontology (Palaeoecology)/ Paléontologie générale, 5, 935-943.

Prelovšek, M., 2005: Excursion to conglomerate karst of Gorenjska region.- In: Karst in various rocks, 13th International Karstological School "Classical karst", 27th -30th June 2005, pp. 16-20, Postojna.

Rodrigues,P., 2011: Speleogenesis of Alecrineiros shaft.Speleogenesis and Evolution of Karst Aquifers. The Virtual Scientific Journal. [Online] Available from: http:// Speleogenesis. Info

Ruddiman, W., Sarnthein M., Backman J., Baldauf J., Curry W., Dupont M., Janecek T., Pokras E., Raymo M., Stabell B., Stein R., \& R. Tiedemann, 1989: Late Miocene to Pleistocene evolution of climate in Africa and the low-latitude Atlantic: overview of leg 108 results.- Proceedings of the Ocean Drilling Program, Scientific Results, 108, 463-484.

Said, R., 1981: The Geological evolution of the River Nile. Springer-Verlag, pp. 151, New York.
Said, R., 1981: The Geological evolution of the River Nile.Springer-Verlag, pp. 151, New York.

Said, R., 1983a: Proposed classification of the Quaternary of Egypt.- J. African Earth Sciences, 1, 41-45.

Said, R., 1983b: Remarks on the origin of the landscape of the eastern Sahara.- J. African Earth Sciences, 1, 153-158.

Salem, R., 1976: Evolution of Eocene-Miocene sedimentation pattern in parts of Northern Egypt.- Amer. Assoc. Petrol. Geol. Bull., 60, 34-64.

Sandford, K., 1934: Palaeolithic Man and the Nile Valley in Upper and Middle Egypt, Chicago University Press, Oriental Institute Publication, 3, pp. 131.

Sultan, M., Struchio, N., Hassan F., Hamdan, M., Mahmoud A., El-Alfy, Z. \& T. Stien, 1997: Precipitation source inferred from stable isotopic composition of Pleistocene groundwater and carbonate deposits in the Western Desert of Egypt.- Quaternary Research, 48, 29-37.

Sweeting, M., 1972: Karst Landforms.- Macmillan, pp. 362, London.

Waltham, T., 2001: Feature pinnacles and barchans in the Egyptian desert.- Geology Today, 17, 101-104.

White, W., 1988: Geomorphology and hydrology of carbonate terrains.- Oxford University Press, pp. 464, Oxford.

Williams, P., 2008: The role of the epikarst in karst and cave hydrology.- International Journal of Speleology. 37,1, 1-10.

Youssef, M., Mansour, H., \& E. Philobbos, 1982: Contribution to the Geology of the area northwest of Assiut, Egypt.- Bull. Fac. Sci. Assiut University, pp. 335-354, Assiut. 